July 1999 • NREL/SR-710-26700

\title{
Financing Solar Energy Systems with Energy Savings Performance Contracts in the Federal Sector: Results of a Survey on Barriers
}

\section{May 1998-January 1999}

Randy C. Gee and Carlo LaPorta Industrial Solar Technology Corporation Golden, Colorado

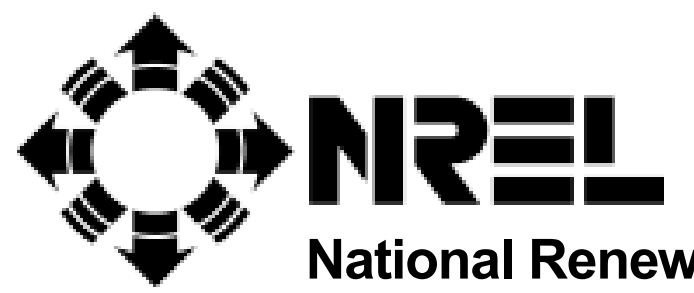

1617 Cole Boulevard Golden, Colorado 80401-3393

NREL is a U.S. Department of Energy Laboratory Operated by Midwest Research Institute $\bullet$ Battelle $\bullet$ Bechtel Contract No. DE-AC36-98-G010337 

July 1999 • NREL/SR-710-26700

\section{Financing Solar Energy}

Systems with Energy Savings Performance Contracts in the Federal Sector:

\section{Results of a Survey on Barriers}

\section{May 1998-January 1999}

Randy C. Gee and Carlo LaPorta Industrial Solar Technology Corporation Golden, Colorado

NREL Technical Monitors:

Patrina Eiffert, Ph.D. and Douglas Dahle

Prepared under Subcontract No. ACG-8-18419-01

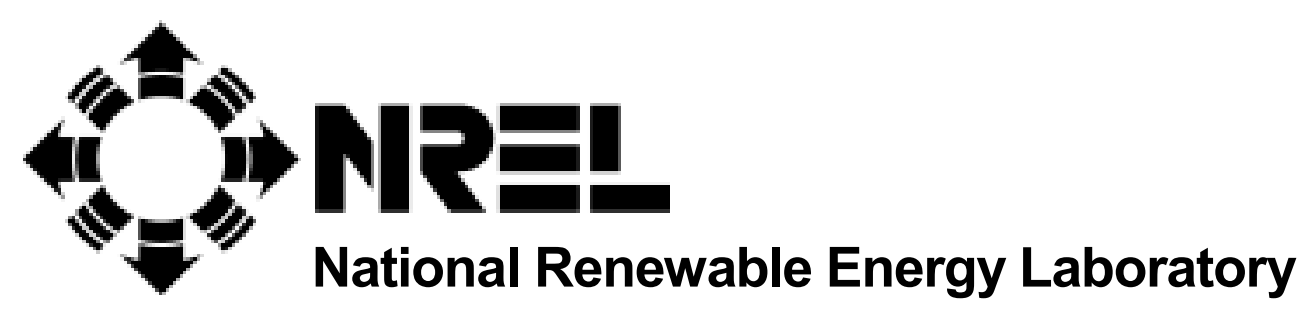

1617 Cole Boulevard

Golden, Colorado 80401-3393

NREL is a U.S. Department of Energy Laboratory

Operated by Midwest Research Institute $\bullet$ Battelle $\bullet$ Bechtel

Contract No. DE-AC36-98-GO10337 


\section{NOTICE}

This report was prepared as an account of work sponsored by an agency of the United States government. Neither the United States government nor any agency thereof, nor any of their employees, makes any warranty, express or implied, or assumes any legal liability or responsibility for the accuracy, completeness, or usefulness of any information, apparatus, product, or process disclosed, or represents that its use would not infringe privately owned rights. Reference herein to any specific commercial product, process, or service by trade name, trademark, manufacturer, or otherwise does not necessarily constitute or imply its endorsement, recommendation, or favoring by the United States government or any agency thereof. The views and opinions of authors expressed herein do not necessarily state or reflect those of the United States government or any agency thereof.

Available to DOE and DOE contractors from:

Office of Scientific and Technical Information (OSTI)

P.O. Box 62

Oak Ridge, TN 37831

Prices available by calling 423-576-8401

Available to the public from:

National Technical Information Service (NTIS)

U.S. Department of Commerce

5285 Port Royal Road

Springfield, VA 22161

$703-605-6000$ or $800-553-6847$

or

DOE Information Bridge

http://www.doe.gov/bridge/home.html

Printed on paper containing at least $50 \%$ wastepaper, including $20 \%$ postconsumer waste 


\section{Financing Solar Energy Systems with Energy Savings Performance Contracts in the Federal Sector: Results of a Survey on Barriers}

\section{Summary}

This report summarizes the findings of an investigation into financing solar energy systems in the Federal sector. The objectives of this study were (1) to identify the barriers that impede companies from using Energy Savings Performance Contracting (ESPC) to develop solar energy projects for Federal facilities, and (2) to clarify the impacts of Federal contracting requirements on ESCOs' use of energy performance contracting for solar projects. Interviews were conducted in 1998 with 24 energy service companies (ESCOs) to gather information in a survey about their experiences with energy service contracts for the Federal government and their attitudes toward these contracts. Following the surveys, recommendations for overcoming these barriers were developed and assessed.

The surveys revealed that there are many barriers to fostering the deployment of solar energy technologies in the Federal sector by using ESPCs. Foremost among these barriers is the longer payback period required for solar system investments, compared with the paybacks for energy conservation measures, such as energy-efficient lighting, which ESCOs now install most often. Solar systems have longer lifetimes (typically 20 to 30 years), however, than many energy conservation measures. So, when they are viewed over their full life cycle, solar projects can be very competitive with efficiency projects. Unfortunately, ESCOs are usually not aware of these economic considerations. So they look for projects with simple payback periods no greater than about 5 years, and this usually excludes solar systems.

Several barriers are directly related to the performance contract itself. For example, the process that begins with identifying project opportunities and ends with concluding ESPC negotiations is too long. This makes it costly and difficult, especially for small companies, to develop projects. And the smaller companies usually have the greatest solar expertise. But even large ESCOs complain about the extra time and money it takes to complete ESPC negotiations. Most ESCOs surveyed also thought that DavisBacon Wage Act requirements should be eliminated from these contracts. When project funding comes from the private sector, Davis-Bacon requirements are seen as inappropriate. They are particularly burdensome for the small businesses that are the key ESCOs attempting to develop solar energy projects today. Similarly, construction bonds can be particularly difficult and expensive for small businesses, and they may not be warranted when projects do not involve government investments.

Another barrier is that most ESCOs, other financing entities, and government facility managers are not aware of the attributes and benefits of solar technologies. And knowledge about the financial incentives that are available to them is scattered. Out in the field, where the true customers are, resistance to solar energy and a lack of knowledge impede progress.

To encourage and foster the deployment of solar technologies in Federal facilities, the government should undertake three main tasks. First, the government should seek ways to accommodate the longer paybacks of solar systems. Second, the Department of Energy's Federal Energy Management Program (FEMP) should modify ESPCs as needed to include more solar projects. Third, FEMP should increase educational and outreach activities, both to ESCOs and Federal agencies, so knowledge about solar energy and the ESPC process will be more widespread. 
FEMP should work with the solar industry, the financing industry, and other stakeholders to make the longer paybacks typical of solar projects less discouraging to ESCOs and agencies. A key recommendation is to create a financing fund that is appropriate for the longer term needs of solar projects and consistent with the 25-year term limit on ESPCs.

The Federal government should also modify the ESPC mechanism it has chosen for performance contracting. The standard contract should be scrutinized with solar projects in mind, certain contract requirements should be revised or removed where possible, and ways of simplifying and shortening the contracting process should be sought and incorporated into the contract. Specific recommendations are provided in this report.

FEMP should increase outreach activities to overcome the barriers that result from a lack of knowledge about solar systems and their economic benefits. A key recommendation, among others, is to create a FEMP Solar ESPC Facilitator System that would expedite the contracting process.

Many Federal agencies may need more information as well as assistance in implementing Executive Order 13123, issued by the President on June 3, 1999. In this order, titled "Greening the Government through Efficient Energy Management," Part 2, Section 204 commits the Federal government to installing 2,000 solar energy systems by the end of year 2000 and 20,000 systems by the end of 2010 . For agencies with limited appropriated funds, an ESPC financing mechanism may be the only way to meet the challenge of this Executive Order. 


\section{Contents}

The Survey.

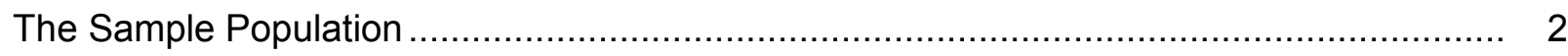

The Companies' Experience with Renewable Energy and Service Contracts................... 5

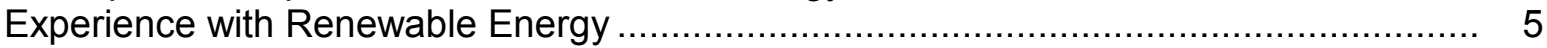

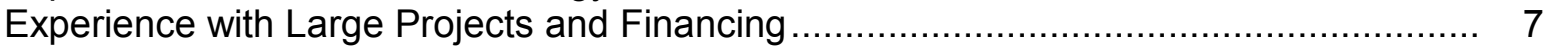

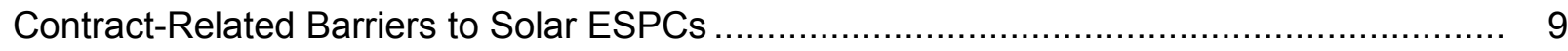

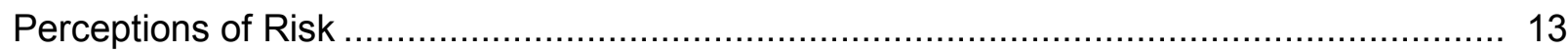

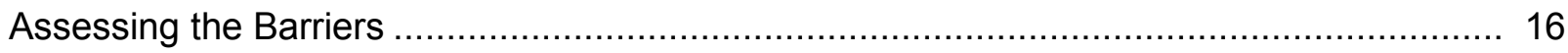

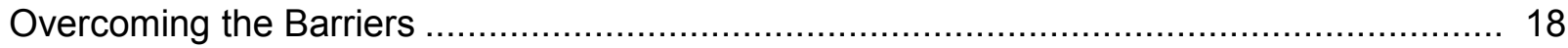

What We Can Do About Long Paybacks ........................................................ 18

What We Can Do About Costly, Time-Consuming Contract Requirements................... 20

What We Can Do About the Need for Information on Solar Systems and ESPCs ......... 21

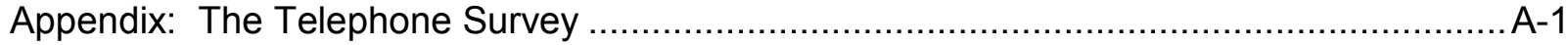

\section{List of Tables}

Table 1. Size and Affiliation of Companies in the Survey Sample ............................... 2

Table 2. Location of Companies Surveyed ........................................................... 3

Table 3. Familiarity of the Survey Company with Renewable Energy ............................. 4

Table 4. Terms of Companies' Energy Service Contracts ....................................... 5

Table 5. Longest Term Considered for an Energy Service Contract.............................. 6

Table 6. Payback Needed to Consider Developing a Solar Project ................................ 6

Table 7. Experience in Bundling Renewable Energy Systems with Conservation Measures .......................................................................................... 6

Table 8. Willingness to Consider Bundling Renewable Energy Projects that Add 2 Years or More to the Payback Period ................................................ 7

Table 9. Knowledge about Renewable Energy Financial Incentives ............................. 8

Table 10. Experience Conducting Pre-Project Audits ................................................ 9

Table 11. Time Needed to Complete ESPC Negotiations after ESCO Conducts an Energy Audit

Table 12. Additional Time Needed for Compliance with ESPC Requirements.................. 10

Table 13. Additional Costs of Compliance with ESPC Requirements ............................ 10

Table 14. ESCOs' Suggestions for Dealing with the Risk Associated with Solar Projects ... 14

Table 15. Characterization of Experience in Complying with Federal ESPC Requirements 16 


\section{The Survey}

In 1998, Federal Energy Management Program (FEMP) staff at the U.S. Department of Energy's (DOE's) National Renewable Energy Laboratory (NREL) awarded a subcontract for assistance with a survey of energy service companies and an analysis of the results. The purpose of the survey was to determine the barriers to developing more renewable energy projects for Federal facilities under energy savings performance contracts (ESPCs). The subcontractors, Industrial Solar Technology Corporation and Capital Sun Group Ltd., prepared a draft questionnaire for use in conducting the survey. Review comments from FEMP staff at NREL were incorporated into the draft, and a few test interviews were then conducted over the telephone, which resulted in more improvements. The final version of the questionnaire, which contained nearly 70 questions, is included in the appendix.

The following information was provided to those who took part in the study:

- Participants were informed that this was a government study to identify barriers to implementing solar and other renewable energy projects through ESPC.

- Participants were told that questions were aimed at clarifying the impact of requirements that the Federal government has created in such contracts, and finding out how their company overcomes any barriers it encounters when conducting performance contract negotiations.

- Participants were informed that responses and other information gathered about their company would remain confidential since they would be aggregated with responses from other companies.

- Participants were told they would receive a copy of the results and the final report. 


\section{The Sample Population}

This section describes the sample population and how it was assembled. The sample population is described according to company size, affiliation, and location. Company names are not included in this report.

The sample population interviewed for this study consisted of 24 energy service companies. Several other companies were interviewed, but the interview showed that they did not have sufficient experience in the Federal arena to make it worthwhile to go through the whole survey. In a few instances, the company representative referred the interviewers to someone else. Even though a complete interview was not conducted, the interviewer kept notes on the additional insights into ESPCs that were provided by these partial interviews and additional contacts.

The list of companies used to create the initial list of contacts was FEMP's September 1998 roster of qualified ESCOs. Initial selections were made to spread out the sample by geographic region and by size; they included 57 companies. The 24 companies that were interviewed were selected for several reasons. For example, either the company's representative was available when called the first, second, or third time, or the representative returned the interviewer's call and expressed a willingness to respond to the survey. Of the 57 companies contacted, 33 did not respond. This means that the sample contains a bias related to the willingness of a company's representative to take the time to go through the 69 questions. Table 1 is a breakdown of the sample population by size and affiliation. States represented in the survey and the number of firms interviewed in each of those states are listed in Table 2.

Fourteen of the companies interviewed (58\% of the survey population) were large businesses. Table 1 shows that 12 of the companies were affiliated with a utility company. Company size turned out to be an important consideration. Several of the survey respondents indicated that they believe that energy service contracting will gravitate to large businesses and that only these large businesses will be able to engage in this market. Although many of these large ESCOs say they have experience with renewable energy, they are not the leading companies when it comes to installations of renewable energy systems. For example, when the companies were asked about their experience with solar systems, photovoltaic technology was the one most often cited (by a margin of about 2 to 1 over other solar technologies).

\begin{tabular}{|c|c|}
\hline $\begin{array}{c}\text { Table 1. Size and Affiliation of Companies in the } \\
\text { Survey Sample }\end{array}$ \\
\hline Large business & 14 \\
\hline Small business & 10 \\
\hline Utility-affiliated & 12 \\
\hline Other-affiliated & 4 \\
\hline Independent & 8 \\
\hline
\end{tabular}




\begin{tabular}{|c|c|}
\hline \multicolumn{2}{|c|}{ Table 2. Location of Companies Surveyed } \\
\hline State & Number Interviewed \\
\hline Arizona & 1 \\
\hline California & 4 \\
\hline Colorado & 2 \\
\hline Connecticut & 1 \\
\hline Delaware & 1 \\
\hline Florida & 1 \\
\hline Maine & 2 \\
\hline North Carolina & 1 \\
\hline Ohio & 1 \\
\hline Oklahoma & 3 \\
\hline Texas & 3 \\
\hline Virginia & 1 \\
\hline Washington & \\
\hline
\end{tabular}

Correlating company size with a company's experience in installing solar or other renewable energy systems showed that eight out of nine small businesses had such experience. Among the large businesses, 10 had experience with solar or renewable energy (two had experience with waste-to-energy systems, and several others had experience with ground-coupled heat pumps). The 10 firms that cited some experience with renewable energy represent $77 \%$ of the large businesses. When they were asked about experience with solar technologies, the "yes" responses of large businesses fell below 50\%. None of the large businesses had much experience developing projects with solar-collector-based technologies. Several had photovoltaic initiatives that were just starting because they were recently qualified by DOE to install PV systems, or because they have bought or partnered with a PV company.

Smaller companies demonstrate the expertise to identify where solar and other renewable energy projects are feasible, but these companies indicated that they are the least able to absorb marketing costs. The large ESCOs are not very far along in developing renewable energy projects; until they purchase solar companies, they will take a long time to ascend the learning curve. Thus, experience with solar systems, and the ability to do solar projects, lies with companies that are most disadvantaged by the government's process for implementing such projects - the smaller companies. This is not to say that the Super ESPC concept is bad. It is clear, though, that much of what has been done has been modeled on the lighting retrofit business, and renewable energy projects often require structures that do not fit this pattern well.

Of the companies surveyed, $75 \%$ said they had experience with solar and renewable energy systems. Only $58 \%$ of all the companies, however, have completed or are in the process of developing a renewable energy project. Three of the sample companies manufacture solar or renewable energy equipment. Two others are connected to a firm that manufactures such equipment.

Table 3 shows the technologies cited by the firms that said they had experience with renewable energy in energy contracting. It should be noted that sometimes this experience came from private-sector projects, or from an investigation of a technology that the company never actually used in a project. Note that Table 3 does not represent the total number of solar energy or renewable energy projects that have been implemented, however. 


\begin{tabular}{|l|c|}
\hline \multicolumn{2}{|c|}{ Table 3. Familiarity of the Survey Company with Renewable Energy } \\
\hline \multicolumn{1}{|c|}{ Renewable Energy Technologies } & Number of Firms \\
\hline Passive solar building technologies, daylighting, ventilation & 6 \\
\hline Low-temperature flat-plate systems & 2 \\
\hline Medium-temperature flat-plate and evacuated tube systems & 4 \\
\hline High-temperature concentrating collector systems & 3 \\
\hline Photovoltaics & 8 \\
\hline Wind & 4 \\
\hline Biomass (includes Municipal Solid Waste) & 4 \\
\hline Geothermal (includes ground-coupled heat pumps) & 8 \\
\hline Hydropower & 2 \\
\hline
\end{tabular}

With regard to renewable energy technologies, the projects cited in the course of the interviews included the following:

- Working on Ft Benning biomass proposal

- U.S. Postal Service waste-to-energy project

- PV in NY medical center and solar domestic hot water system repair

- Transpired collector for preheating ventilation air

- Landfill gas

- None yet, but have GSA PV agreement in hand

- None yet, but have DOE PV IDIQ [indefinite delivery/indefinite quantity contract]

- Solar thermal trough hot-water systems for prisons and recreation center

- For two Navy air stations, ground-source heat pumps

- County courthouse third-party-financed ground-source heat pump

- Daylighting, USPS and Air Force hangars; use PV for tracking motors

- Daylighting and ventilation

- Early 1980s Federal solar hot water and private wood waste cogeneration project

- Ground-source geothermal heat pump, 200 tons at laboratory 


\section{The Companies' Experience with Renewable Energy and Service Contracts}

For the sample population, the number of energy service contracts cited totaled 280. The interview discussions indicated that many of these involve companies that qualified as area-wide or agency-wide contractors responding to requests for bids for energy retrofits. No questions were asked to further qualify this number to distinguish between performance contracts and straightforward energy conservation work that was paid for with appropriated funds.

The sample population reported that 116 contracts were in development. Companies that had IDIQ taskorder type contracts for a certain region, for the whole country, or with particular agencies have used them as a springboard to develop a large share of their business. It should be noted that the interviews turned up a few companies that were qualified ESCOs on DOE's roster but that had not done Federal projects. They stated they were merely interested in being designated a qualified ESCO for their corporate resume.

\section{Experience with Renewable Energy}

Fourteen companies in the survey reported that a Federal agency had asked them about doing a renewable energy project. A large majority, 20 out of 24 interviewees, stated that if they needed to add a solar component to a project in order to get an ESPC, they would do so. Some qualified the positive response to say it would depend on the economic viability of the technology. Often an answer would indicate that much depends on what the customer wants. This cannot be stressed enough: the interest and capabilities of government staff largely determine a project's viability and success in the energy service contracting business. ESCOs need willing contracting officers and facility managers to make these arrangements work.

Tables 4 through 7 provide information about the companies' experience with contract terms and paybacks. The tables also indicate the experience companies have had with including renewable energy systems in projects involving more conventional energy conservation measures (i.e., "bundling" renewable systems and energy conservation measures).

\begin{tabular}{|c|c|}
\hline $\begin{array}{c}\text { Table 4. Terms of Companies' Energy Service } \\
\text { Contracts }\end{array}$ \\
\hline Term of Contracts & Number of Respondents \\
\hline 3 years or less & 2 \\
\hline 5 years & 6 \\
\hline 7 years & 1 \\
\hline 10 years & 9 \\
\hline More than 10 years & 3 \\
\hline
\end{tabular}




\begin{tabular}{|c|c|}
\hline $\begin{array}{c}\text { Table 5. Longest Term Considered for an Energy Service } \\
\text { Contract }\end{array}$ \\
\hline Term & Number of Respondents \\
\hline 3 years & 0 \\
\hline 5 years & 3 \\
\hline 10 years & 6 \\
\hline 15 years & 1 \\
\hline 20 years & 13 \\
\hline
\end{tabular}

\begin{tabular}{|c|c|}
\hline $\begin{array}{c}\text { Table 6. Payback Needed to Consider Developing a Solar } \\
\text { Project }\end{array}$ \\
\hline Simple Payback Time & Number of Respondents \\
\hline Less than 5 years & 12 \\
\hline 7 years & 7 \\
\hline 10 years & 2 \\
\hline 15 years & 2 \\
\hline
\end{tabular}

\begin{tabular}{|l|c|}
\hline \multicolumn{2}{|c|}{$\begin{array}{c}\text { Table 7. Experience in Bundling Renewable Energy } \\
\text { Systems with Conservation Measures }\end{array}$} \\
\hline \multicolumn{1}{|c|}{ Action } & Number of Respondents \\
\hline Tried or trying & 8 \\
\hline Only considered & 10 \\
\hline Never considered & 7 \\
\hline
\end{tabular}

Table 4 shows that half the respondents were involved in contracts that typically run for 10 or more years. Some respondents indicated they would go with longer contracts, and some have signed contracts that run for more than 20 years. In these instances, the projects involved some infrastructure improvement. The data indicate two types of activities: large projects that have 10-year paybacks as the norm, and smaller projects that involve retrofits with 3- to 5-year simple paybacks. The important consideration for those interested in solar systems is that many of the companies are open to longer contract periods. Table 5 shows that 13 companies would negotiate 20 -year or longer contracts. The rest cluster around 10 years.

Table 6 indicates where a difficulty arises. Fully half the respondents would require that a renewable energy technology project have a simple payback of 5 years or less. Seven of the respondents said 7-year terms were acceptable. Only four would consider 10- and 15-year simple paybacks. This shows that the industry is still focused on 10-year contract projects. The desire for a 5-year payback fits in with the interview results; a number of companies indicated that their rule of thumb is to double the simple payback to determine the contract length needed to cover all the implementation, overhead, and financial costs of these projects. 
The simple payback issue is compounded for many renewable energy technologies because manufacturers need to increase production to reach economies of scale, and the Federal sector appears to be a market in which the most progress can be made. Nearly everyone in the ESPC business appears to be looking at simple paybacks to initially define and evaluate project opportunities, making this somewhat of a chicken-or-egg situation. Furthermore, a number of interviewees said they believe the Federal sector is ahead of the private sector when it comes to bundling energy conservation technologies in projects and signing longer term contracts. Private-sector customers appear to be much more likely to limit a contract to a single energy conservation measure. One person interviewed also noted that the success rate for completing negotiations once project proposals are prepared is much higher (as much as four or more times higher) with a Federal customer than with one from the private sector. This again suggests that there should be a premium on opening up the Federal market for renewable energy technologies.

Table 7 shows that eight (one-third) of the respondents have tried to bundle a renewable energy project with an energy conservation one. Seventeen have only considered it or have never tried it. As noted earlier, 20 respondents said they would add a renewable energy system to a project if they needed it to gain project or contract approvals. And 21 of the 24 companies said that if adding a solar energy system added 2 or more years to a project's term, they would be willing to add the system.

The survey's results can be interpreted in several ways. One can surmise that these companies are in business to meet their customer's needs and wants. They understand that the Federal government is interested in installing more renewable energy systems (e.g., as in the Million Solar Roofs Initiative), and since they are in this arena, they see a need to consider such projects. The bottom line, however, is that they are driven by their business requirements and by needing an acceptable return on investments. One utility-affiliated firm observed that getting customers to sign long-term contracts keeps them as customers, which may have increased value in a market moving toward deregulation and the ability to buy power from several providers. But on balance, ESCOs have to satisfy the requirements of their sources of capital, the guidelines established for project contract terms, and the comfort level of the government staff they work with on projects. These can represent a difficult set of hurdles to overcome in trying to increase renewable energy projects.

\begin{tabular}{|c|c|}
\hline Table 8. & $\begin{array}{l}\text { Willingness to Consider Bundling Renewable } \\
\text { Energy Projects that Add } 2 \text { Years or More to } \\
\text { the Payback Period }\end{array}$ \\
\hline Response & Number of Firms \\
\hline Yes & 21 \\
\hline No & 3 \\
\hline
\end{tabular}

\section{Experience with Large Projects and Financing}

Twenty of the respondents indicated a minimum project dollar value or range of values needed for energy conservation and renewable energy projects. Only six of the firms would accept contracts under $\$ 100,000$ in value, and three companies would accept contracts between $\$ 100,000$ and $\$ 500,000$. Four companies indicated a minimum contract value of $\$ 500,000$, and seven companies said their minimum was $\$ 1$ million or more. In the group that said they would go under $\$ 100,000$, the maximum they cited ranged between $\$ 1$ million and $\$ 2$ million. For the firms with larger minimums, the upper end of project values ranged between $\$ 10$ million and $\$ 25$ million. These data suggest that companies feel they have to 
do large-value contracts in order to justify the development effort and costs associated with working in this arena. The project values also suggest that larger solar energy projects can fit within these value ranges. No questions were asked to further define whether a solar system that could add $\$ 1$ million to a project would be of particular value to firms interested in negotiating larger contracts with longer terms.

These companies' project financing structures primarily involve third-party financing organizations or groups. Fourteen companies cited debt as the means of financing projects. Banks are not involved; rather, companies like GE Credit and Energy Capital Partners are the primary financers. Some companies put together limited liability corporations for equity deals. Only five companies used internal equity only for projects. Five used a mixture of debt and internal equity, and three used debt and external equity.

With regard to using various financial incentives to offset the cost of renewable energy projects, six companies said they had made use of an incentive program. The measures used were Federal tax credits (noted by four companies), state tax credits (noted by four companies), and a government grant to buy down the initial system cost (noted by one company). Knowledge about the various incentives was not widespread. About half the respondents knew about several of them.

Sixteen of the firms said that they used depreciation schedules when they were calculating the value of a project to them. It appears that many project developers were either not aware of financial aspects, or they would establish the project's scope and then turn the money matters over to the financial department. Answers to specific questions about knowledge of financial incentives are in Table 9.

\begin{tabular}{|l|c|c|}
\hline \multicolumn{1}{|c|}{ Table 9. Knowledge about Renewable Energy Financial Incentives } \\
\hline & $\begin{array}{c}\text { Did Know } \\
\text { About It }\end{array}$ & $\begin{array}{c}\text { Did Not Know } \\
\text { About It }\end{array}$ \\
\hline California state PV rebate program & 11 & 13 \\
\hline $\begin{array}{l}\text { Five-year depreciation of solar and } \\
\text { renewable equipment }\end{array}$ & 10 & 14 \\
\hline $\begin{array}{l}10 \% \text { Federal tax credit for } \\
\text { commercial solar energy systems }\end{array}$ & 13 & 11 \\
\hline $\begin{array}{l}\text { Federal energy production credit } \\
\text { for wind and biomass power }\end{array}$ & 6 & 18 \\
\hline
\end{tabular}




\section{Contract-Related Barriers to Solar ESPCs}

The survey questionnaire contained a series of questions designed to identify and assess the impact of the barriers that ESCOs encounter when they develop energy service projects. The questions came in part out of Industrial Solar Technology's experience working on Federal solar projects; one project is under way but several others have not yet been approved. The questions related to specific ESPC contract requirements, and interviewers asked company representatives to respond by describing or assessing their experiences. Some questions asked them to pick an answer from a list of options; others asked for a general opinion or impressions. The survey asked about time considerations as well as general and specific questions about such requirements as proving that a contractor had project financing within 30 days of a signed agreement to go forward with a project.

The survey contained several questions about the time and cost of completing energy service contracts with the Federal government and how those compare with the time and cost of work for non-Federal customers. The survey started by asking companies whether they had encountered problems when it came to conducting pre-project energy audits, and to indicate how much time such problems added to project development. The question was asked because some solar companies have found it difficult to obtain access to Federal facilities and get accurate information from them. Table 10 shows that 10 of the surveyed companies said they had difficulties in this stage of project development.

\begin{tabular}{|c|c|c|}
\hline \multicolumn{3}{|c|}{ Table 10. Experience Conducting Pre-Project Audits } \\
\hline Did the company have a problem? & Yes & 10 \\
\hline & No & 12 \\
\hline & No Answer & 2 \\
\hline $\begin{array}{l}\text { How much time did this } \\
\text { problem add to project development? }\end{array}$ & \multicolumn{2}{|c|}{ Number of Respondents } \\
\hline Less than 30 days & \multicolumn{2}{|c|}{8} \\
\hline 2 to 3 months & \multicolumn{2}{|l|}{5} \\
\hline 6 to 12 months & \multicolumn{2}{|l|}{1} \\
\hline More than 12 months & \multicolumn{2}{|l|}{0} \\
\hline
\end{tabular}

Table 11 lists the company representatives' comments about the amount of time it takes to complete an ESPC-type contract with the Federal government, and how that compares with that of the private sector and non-Federal government groups. A simple count shows that 12 months or more was the most common answer for the Federal sector.

The companies in the survey were asked to indicate how much project time must be added to comply with Federal government contract terms. Responses are tallied in Table 12. Responses to a similar question about costs are tallied in Table 13 . In both cases, $67 \%$ of the respondents said that complying was either a burden or that it added too much time and cost to a project. 


\begin{tabular}{|l|l|l|}
\hline \multicolumn{3}{|c|}{ Table 11. Amount of Time Needed to Complete ESPC Negotiations after ESCO } \\
Conducts an Energy Audit \\
\hline \multicolumn{1}{|c|}{ Federal Sector } & \multicolumn{1}{|c|}{ Private Sector } & Other Government Group \\
\hline $12+$ mos & 4 to 5 mos & Schools take 8 mos \\
No Federal projects, but 18 mos is & 3 to 9 mos & Federal is twice as long \\
normal & $6-12$ mos & Same \\
Haven't done one yet & 6 to 12 mos & 5 mos \\
22 mos with Post Office, not there yet & Federal takes much longer & 6 mos \\
$6-12$ mos & Federal takes longer & Federal is much longer \\
12 to 48 mos & 2 to 3 mos & In between Federal and private \\
12 mos & 1 to 3 mos & 6 to 9 mos \\
12 mos if audit & Same as federal & Same \\
12 to 24 mos & 6 mos & 12 mos \\
One project, 12 months (4 to get task & Federal is way longer & Like Federal \\
order, 8 more for signature) & Federal is 3 to 4 times & (Total = 11 responses) \\
2 mos & longer & \\
6 mos & 3 mos & \\
No ESPC experience & Same as federal & \\
Depends on project size, 24 to 36 mos & 12 mos & \\
6 to 24 mos & Federal is longer & \\
Too long, one was 5 years & (Total = 16 responses) & \\
6 to 9 mos & & \\
12 mos-24 mos & & \\
2 mos on one project by bid & & \\
(Total = 19 responses) & & \\
\hline
\end{tabular}

\begin{tabular}{|c|c|}
\hline $\begin{array}{c}\text { Table 12. Additional Time Needed for Compliance with ESPC } \\
\text { Requirements }\end{array}$ \\
\hline Response Choices & Number of Respondents \\
\hline None & 2 \\
\hline A small amount & 3 \\
\hline Enough to be a burden & 8 \\
\hline Too much & 8 \\
& (Total $=21)$ \\
\hline
\end{tabular}

Table 13. Additional Costs of Compliance with ESPC Requirements

\begin{tabular}{|c|c|}
\hline Response Choices & Number of Respondents \\
\hline No additional costs & 2 \\
\hline A small amount & 3 \\
\hline Enough to be a burden & 11 \\
\hline Too much & 4 \\
& (Total $=20)$ \\
\hline
\end{tabular}


The survey also requested information about payment and performance bonds. Bond costs generally vary from under $1 \%$ of the project budget to $2 \%$. In some cases, for small businesses, even higher costs $(4 \%)$ were cited, since bond costs are based on perceived risk. For small companies that work in an environment that doesn't typically require bonds, the costs and time delays associated with obtaining bonds is very burdensome. In theory, the bonds add protection for the government. But some companies wonder if bond protection should be required when government funds are not at risk. It is argued that, if any entity deserves bond protection, it should be the one that finances the project, since it is that entity's funds that are at risk. Opinion was divided about the need to have bonding; a number of respondents indicated that bonds are waived in their negotiations.

Fourteen companies (58\%) thought bonds should be eliminated since the government is not at risk. Ten companies thought the bonds should be retained. One firm indicated that it had the bonding requirement removed once the contracting officer viewed the contract as a "service contract" rather than a "construction contract." Another firm suggested that the contract just require coverage to restore the facility to its pre-project state, which would greatly lower the bonding cost. Bond costs have a measurable impact on the bottom line of the companies involved, and for projects with longer paybacks (e.g., solar projects), bond costs can have an impact on a project's viability.

The Davis-Bacon Wage Act (Pub. L. 88-349, 40 USC Sec. 276a) requires that laborers and mechanics be paid the minimum negotiated wage for their trade for all work done under Federal contracts exceeding $\$ 2000$ in value. All but one of the firms surveyed cited the drawbacks associated with this provision. The main drawback cited was an increase in wages for such workers (67\% so responded). One company that works on rather small-scale projects found that this requirement adds $5 \%$ to $10 \%$ to its costs. Another firm said it had to charge the government $\$ 53$ per hour for a mechanic just to change lamp ballasts. One-third of the companies cited the extra paperwork burden associated with this requirement, and one-third cited the extra time it takes to comply.

Thirteen of the respondents (54\%) thought that Davis-Bacon requirements could be eliminated because these projects are privately funded and owned. In contrast, other companies noted that they simply had to comply. In some cases, union labor was preferred if it was higher in quality. And in some locales, union scale was what companies paid anyway. A few companies said the provision played havoc with pay scales in their company, or caused problems when they worked with a subcontractor.

Regarding the requirement that firms prove they have financing within 30 days of signing their performance contract, 18 respondents said that this was not a problem, one said it was moderately difficult to comply with, and three said it was hard. Small companies in the entry mode are more likely to need extra time, because finance companies can take months to find out what they need to know about renewable energy technologies to feel they have exercised "due diligence." This is a considerable hurdle for the smaller companies, and 11 of the respondents thought the requirement should be eased for small businesses. But even when a large company has a multi-million-dollar project in the works, and the source of financing takes several months to be satisfied about bundling a solar technology into a project, an ESCO may grow impatient or concerned about interest rates and decide to drop the solar component.

Regarding the assignment of claims provision, only one company said this had been a major problem. Many company representatives were not sure what this is, however, so they leave it up to the finance people in their company to figure out. The one problem that occurred was due to a lack of contracting experience on the part of the government, specifically with assignment of claims issues. This resulted in considerable expense and several months of delays (including legal fees paid by the private financer) to the solar project. In fact, this one issue came very close to "killing the deal." Thus, while the issue does not appear to be a widespread problem, it can sometimes be an important one. 
The question about how ESCOs typically handle ownership of equipment in their projects showed that almost $67 \%$ of them retain ownership until the end of the contract term. Of the population surveyed, $29 \%$ immediately turn over the equipment to the government. Three companies (13\%) said they sell the equipment at the end of the term.

The companies' response to a question about retaining or eliminating the requirements for installation and quality control plans for these projects indicated that they believe these plans are necessary. Even though the government was not investing capital in the projects, 19 companies (79\%) thought the plans are a sound business practice and should be retained. Only three companies said this provision was a problem for them.

The survey asked a question about government contracting officers helping or hindering the process of working on the guaranteed performance aspect of a contract. It appears that most respondents regarded this question more generally, that is, they related it to help in getting contracts in place, not working on the guaranteed savings part. Of the 21 companies that responded, 11 said contracting officers were helpful, 3 said they had no impact, and 7 said they hindered the process. These are important questions for ESCOs because they understand that the comfort level of their customers determines a lot of what goes into a project and a contract. Some respondents made it clear that the customer rules, and this has both positive and negative aspects.

The survey question about the government being a help or hindrance asked specifically about contracting officers. In retrospect, it is clear that a question should also have been asked about the facility managers and engineers involved in project approvals. Several companies attributed a lot of their problems to these individuals. Another barrier appears to be the high turnover in government personnel, particularly military staff and Department of Defense (DoD) civilian employees. In these areas, outgoing people do not usually train their replacements. Since it already takes 12 to 24 months to get a project negotiation completed, the potential extra delays caused by changes in personnel pose additional problems for these projects.

One respondent said that the energy services concept does not work in the Federal government for new technologies, and that government staff will pick apart and second-guess everything. This company looked at a Super ESPC opportunity and decided that the entry costs were too high for them. Another firm found that using commonly accepted business terminology caused such a problem that in one instance the company was eliminated from a solicitation. The representative recommended that the government accept the standard practices and terminology found in the private sector and be more diligent in looking out for the interests of the taxpayer.

With regard to reporting to DOE on a monthly basis, only two companies indicated that this requirement had caused them a problem. Nine firms indicated, however, that they thought this requirement should be eased for small businesses, and some responded that the DOE official was not involved in the project so it became a situation of "bean counting." Several firms suggested that such reporting could be done quarterly. 


\section{Perceptions of Risk}

If they did not have any experience with renewable energy, the companies surveyed were asked what it would take for them to become more interested. The following answers were provided:

- Need more knowledge (of) PV O\&M, need to have a strong RE partner firm

- Have abandoned Federal sector

- Knowing that paybacks were lower (feels they are too long; eastern shore has lower electricity costs)

- Are looking now for PV

- Solar needs to become cost-effective

- See market opportunity to be small cogeneration for Navy in Pacific Rim, 35 to $150 \mathrm{~kW}$

- Just won DOE IDIQ for PV

- Commercial viability; economics kill projects

- Better paybacks to meet Federal 10-year term threshold, looking at geothermal

- Technology with 3- to 5-year payback

The survey also asked the companies, "When it comes to contracts that involve solar energy or renewable energy technology, what does your company think are the main risks for ESCOs?" The following responses were given:

- Achieving the savings

- The technology is passing the technical risk test and challenge; worry about the solar industry supporting infrastructure; it's a small group

- Learn the technology well

- Vandalism and theft for PV

- Vendor going out of business, customer awareness and willingness, cost-effectiveness

- See technical viability, worry about higher costs

- Managing the customer

- Short track record of solar companies, longer paybacks for solar equipment, and poor solar track record in early 1980s

- Uncertainty over performance modeling and guarantees

- How to negotiate fair and reasonable contract for stochastic resource

- Overestimating savings and not meeting estimated payback due to unknown technology

- Unknown technology

- New technology that is changing and fact that technology may have been oversold

- Front end development time excessive for government sales, and have all-or-nothing awards from government

- Weather's effect on performance

- New unproved technology

- Less proven technology

- Performance of technology and overall economics

- If tax credits are used, stay in place for term of contract, and operation/maintenance practices for performance

- Weather and equipment reliability

- Technology not well understood, which adds time 
The responses confirm what companies in the solar business know: solar energy companies are perceived to be a transitory lot without long-term company histories, and doubt remains about how well the technologies will work. The concern about a solar company's staying power should be a non-issue. The flat-plate solar collector manufacturing industry shook out in the mid-1980s, when the Federal residential tax credits expired and the business credit was reduced to $10 \%$. Companies still in the business have been in existence for 15 years or more. With regard to transpired solar collectors and parabolic troughs, the industry has to contend with the fact that only one company exists for each technology. The companies that have commercialized these systems market them as aggressively as possible with the resources they have. But it seems to be a rule in the marketplace that consumers' confidence in a product goes up when a second company enters the field selling the same product. For now, the firms manufacturing transpired solar collectors and parabolic troughs have no competition. For concentrating collectors, one of the large utility-affiliated ESCOs is developing a system, and BP Solar has a one-axis tracking PV system using parabolic trough technology. However, the product visibility of concentrators remains low, and more market exposure is needed.

The interview form asked the companies to indicate how they would compensate for the risks associated with incorporating a solar system in a project. Table 14 records the answers to the four options given in the questionnaire. It shows that bundling renewable energy and requiring the renewable energy companies to offer performance guarantees were selected most often.

\begin{tabular}{|c|c|}
\hline \multicolumn{2}{|c|}{$\begin{array}{l}\text { Table 14. ESCOs' Suggestions for Dealing with the Risk } \\
\text { Associated with Solar Projects }\end{array}$} \\
\hline Risk Abatement Option & $\begin{array}{l}\text { Number of } \\
\text { Responses }\end{array}$ \\
\hline Raise rate of return requirement & 2 \\
\hline Bundle with energy conservation measures & 7 \\
\hline Keep solar a small percent of project & 4 \\
\hline Require performance guarantees for solar & $\begin{array}{c}7 \\
(\text { Total }=20)\end{array}$ \\
\hline
\end{tabular}

The companies also offered their opinions about the main contracting-related risks associated with renewable energy technologies for Federal agencies. Those opinions are as follows:

- Lack of guarantee of energy costs in the future, government still has to pay contract

- Performance and risk management.

- They risk not doing these projects and taking a political hit

- Lack of familiarity with solar

- Cost vs payback; if higher-ups see longer payback, they will cut project from budget

- Dealing with budget-funded projects and the need to show ability to pay for project

- Afraid of criticism for signing a bad deal

- Getting them to accept that this is not spec and bid work

- How it's done is not government concern; risk is minimal

- Savings are the end product, not the technologies used

- Requires 20- to 25-year contracts with companies with relatively short histories

- Rate risk from deregulation 
- Maintenance-savings credits to contracts

- Overestimating savings and not meeting estimated payback due to unknown technology

- Only risk is technology may never pay for itself

- None really

- Politics

- If contractor doesn't finish job midstream in construction

- None with simple technology, proper front end design

- Unproven technology

- Political, get questioned about projects with longer paybacks

- Performance of technology and overall economics

- Obsolescence of equipment before term ends

- Only same as for other technologies as long as equipment is good and properly installed

The responses to the question about the performance contract risks that ESCOs perceive for the Federal government parallel those stated for the ESCOs themselves. An exception is acknowledging the fact that government staff work in a political environment, which affects their job and how they do it. The ESCOs noted that for government staff, there is an added element of anxiety because of the scrutiny from above inherent in government work. The lowest-risk position is almost always to do nothing, and this is rewarded with a sense of tranquility on the job.

Another risk cited has to do with the lack of familiarity with the ESPC mechanism. Some ESCOs have it down pat, but the Federal staff they work with often have a significant learning curve to climb. This again underscores the need for comprehensive education programs and materials, or an alternative solution, such as a team of performance contract specialists that could easily and rapidly assist contract officers whenever performance contracting is considered. 


\section{Assessing the Barriers}

A broader opinion question was added to the survey questionnaire to get a general impression of companies' experience with Federal energy service contracting. It was worded as follows: "Given the contractual provisions the Federal government requires for ESCO projects, how would you characterize, in general terms, your experience in completing this kind of contract?" The respondents were given four choices for their response, as shown in Table 15.

\begin{tabular}{|c|c|}
\hline $\begin{array}{c}\text { Table 15. Characterization of Experience in Complying } \\
\text { with Federal ESPC Requirements }\end{array}$ \\
\hline Possible Responses & Number of Responses \\
\hline Not a problem & 5 \\
\hline Mild annoyance & 5 \\
\hline A hassle & 6 \\
\hline A severe burden & 5 \\
& (Total =21) \\
\hline
\end{tabular}

As shown, the responses were spread almost evenly among the four choices. One might expect that the larger firms would find it easier to comply, because the scale of their projects does not put as much pressure on them to cover "overhead" or administrative costs in the project budget. However, eight of the large businesses said that complying was either a hassle or a severe burden. And five of the small businesses said that it was either not a problem or a mild annoyance. This is counter-intuitive, but it appears that an explanation may be found in looking at the scale of the projects generally undertaken by the large and small businesses. The larger companies are often involved in larger, big-dollar projects, and the pressures and uncertainties that government staff often feel when working on transactions of this size and expense can increase the amount of approvals, steps, and time involved in these projects.

It is clear that both large and small businesses participating in this survey believe that a number of the barriers to greater use of Federal ESPCs are serious. These can be summarized as follows:

Long Paybacks for Solar Systems - First and foremost among the barriers is the longer payback period associated with solar installations, in comparison to the energy conservation measures usually installed by ESCOs. However, most solar systems are designed to have longer lifetimes (sometimes up to 30 years) than most energy conservation measures. So, when they are viewed over their full life cycle, solar systems might be more desirable. Unfortunately, however, ESCOs are not aware of this, and they usually seek projects with simple paybacks no greater than 5 years. This usually excludes solar systems.

The other main impediments involve the performance contract itself. If the government wants to encourage the deployment of renewable energy technologies in its facilities, it must modify the mechanism (the ESPC) that it has chosen to help accomplish this goal. The contract-related barriers follow.

Time-Consuming Contracting Requirements - The process used to identify project opportunities and complete negotiations takes a long time. This makes the use of ESPCs costly and difficult for many companies, especially the small businesses that have the expertise in renewable energy needed to develop projects. However, even the largest ESCOs complain about the amount of time and money it takes to complete ESPC negotiations. Some of the barriers that follow may be adding to the length of these projects. 
Inappropriate Davis-Bacon Wage Act Requirements - Fifty-four percent of the companies surveyed thought that Davis-Bacon wage requirements should be eliminated from these types of contracts. When project funding is private, Davis-Bacon Act requirements are seen as inappropriate. They are particularly burdensome for the small companies that form the core of those attempting to develop solar energy projects.

Unnecessary Performance and Payment Bonds - Given the longer payback times for renewable energy projects, anything that adds costs to a project hurts the prospects for a technology to be adopted by an ESCO or developed by a renewable energy company. Performance and payment bonds may not be warranted when project costs do not involve government investments. Bonds can be particularly difficult and expensive for smaller companies, and they can add up to $4 \%$ to the cost of a project.

Lack of Familiarity with Renewable Energy Technologies and Performance Contracting - Large ESCOs and government facility managers are for the most part unaware of the attributes of renewable energy technologies, and knowledge of the financial incentives for installing them is scattered. A gap exists in the Federal government between the site managers and regional or agency managers who want more energy conservation and renewable energy systems installed. Out in the field, where the real customers are, resistance and a lack of knowledge about renewable systems are impeding progress.

Unrealistic Proof-of-Financing Requirements - Small businesses often find that providing proof of financing within 30 days after acceptance of an installation plan can be difficult if not unrealistic. Large companies usually have such financial strength that proof of financing is a non-issue, but small businesses typically do not have a standing arrangement with a financial partner. Rather, each project requires scrutiny by potential financing companies or groups, and the financial health of a small ESCO will also be investigated. This process can consume much longer than the 30 days required for an ESPC.

Uncertain Ownership of Equipment - There is a 10\% Federal tax credit available as an incentive to the owner of the solar system and related equipment installed as part of a solar project. However, if the government automatically becomes owner of the equipment at the end of the contract (as specified in current Super ESPCs), the tax credit may be unavailable under certain financing arrangements.

Need for New DOE Reporting Requirements - With regard to the Super ESPC requirement to report to DOE on a monthly basis, only two companies indicated that this requirement had caused them a problem. But in some cases, the requirement is simply ignored. Nine firms indicated that they thought this requirement should be eased for small businesses, and there was a perception that the DOE official was not involved in the project so it was an issue of "bean counting." Several firms suggested that such reporting could be done quarterly. 


\section{Overcoming the Barriers}

Some significant barriers must be overcome before the solar industry can be expected to make widespread use of Federal energy performance contracting and meet its goal of expanding sales. Two key objectives of this study were (1) to find out what experiences ESCOs have had with solar energy and energy performance contracting, noting especially the barriers to solar projects that they have encountered, and (2) to recommend actions that FEMP could take to make ESPCs a more powerful means of expanding the use of renewable energy in Federal facilities.

The primary barriers discussed in the previous section fall into three general groups: (1) long solar system paybacks, (2) costly and time-consuming contracting requirements, and (3) a lack of familiarity, on the part of both ESCOs and facility managers, with solar energy technologies and energy performance contracting. Several recommendations for overcoming these barriers follow, along with a brief discussion of the rationale for these recommendations.

\section{What We Can Do About Long Paybacks}

The greatest barrier to having a larger number of ESPCs involving solar energy technologies is the comparatively long paybacks associated with solar energy systems. Most conventional energy conservation measures (lighting retrofits, energy management control systems, efficient cooling, etc.) have paybacks of 3 to 6 years. But solar projects generally have longer paybacks, typically 7 to 15 years, that require longer financing (15 to 25 years) than efficiency and conservation measures. In the current market, financing for performance contracts often has a maximum 10-year term. This amount of time is sufficient for conventional energy conservation measures, but not for most solar projects. The following recommendations address these issues.

\section{Recommendations}

Create a Financing Fund for Solar Energy Technologies - The government should sponsor the creation of a public-sector/private-sector financing entity that provides low-interest loans on a 15- to 25year term for solar energy projects. Public participation, along with that of private-sector institutions, is suggested because it might be necessary for the government to help jump-start such an entity. An implementation plan could emerge from the solar industry, working closely with FEMP and the financing industry, and other stakeholders could be engaged early in the process to develop and implement this fund. A revolving fund, or a similar vehicle, might be the best solution. One precedent for this approach is the Small Business Energy Loan Program established in California. It offered solar energy companies loans at 5\% interest for project implementation. Other states may also have such programs, or they could be creating them with funds flowing into trusts for renewable energy from basic service charges established as part of utility restructuring. Private-sector participation is a key ingredient, as is the involvement of many other potential stakeholders, such as state energy offices, solar and renewable energy trade associations, economic development groups, and commerce departments.

Aggressively Promote “Bundling” of Solar Systems with Energy Conservation — The government should develop the "bundling" concept, in which solar energy systems are included in ESPC projects with more conventional energy conservation measures. Combining short-term conservation measures and long-term solar technology measures can provide a greater energy-savings impact in a Federal facility. This should also help to meet the private sector's criterion for shorter paybacks, which is 
especially true among energy service companies and financing groups. The bundling concept is specified as an allowable contract element in Technology-Specific Super ESPCs, but it appears that DOE has not strongly promoted it. To expand the use of bundling, FEMP could suggest that all Super ESPCs include a requirement that a specified minimum portion of such projects include solar energy systems (perhaps $10 \%$ by value) as part of each task order. Such a requirement could be a powerful deployment engine for solar systems, particularly in projects with an overall payback of 5 or 6 years or less.

Allow “Front-Loading” of Energy Costs for Renewable Energy Projects - The government should promote and encourage the concept of allowing "front-loaded" or "levelized" solar energy revenue streams. This means that the Federal facility would pay more than current fuel costs in the early years of a project, and save more in the later years. Because of the relatively short paybacks and lifetimes of many conventional energy conservation measures, this approach is not necessary in energy efficiency projects. For solar projects, however, with longer paybacks and lifetimes, the concept can be helpful. Front-loading is likely to help the solar project's economics and result in greater overall energy savings for the government. California established this precedent in its standard-offer contracts for PURPA (the Public Utilities Regulatory Policies Act) projects in the 1980s. The approach needs to be analyzed, however, to ensure that it complies with the requirements of EPAct (the Energy Policy Act of 1992) for guaranteed savings. It appears that legislation requires savings to exceed payments in each year of the contract term, which does not allow "front loading."

Include O\&M Savings from Solar Projects as a Revenue Source - The government should inform the facility engineering community about the fact that solar energy systems will reduce operation and maintenance costs when they are added to or replacing conventional energy systems. In solar water heating projects, for example, results include longer boiler and heater lifetimes and less frequent replacement of water-heater elements. The O\&M savings can be incorporated into solar system ESPCs. Many ESPCs using conventional energy conservation measures incorporate O\&M savings, but at present this additional revenue source is not being used in solar projects.

\section{Discussion}

An ideal ESPC situation would be for ESCOs to accept the economics of solar-only projects and get financing from their usual sources. This survey showed, however, that ESCOs apply a "2 times" rule when considering these projects. For example, if the simple payback for a project is 5 years, then the project term needs to be 10 years for the company to be able to obtain an adequate return on its investment. Of the 21 respondents who cited a typical term for the energy service contracts they engage in, 18 said they were less than 10 years in length. Even though 13 respondents said they would consider contract terms as long as 20 years, 12 respondents said they would need to see a simple payback of 5 years or less to consider a renewable energy project, and 7 respondents put the figure at 7 years or less.

In the current marketplace, conventional energy prices are quite low, so the volume of sales (and thus production) in solar energy companies is not high enough to lower per-system costs. The goal is to obtain longer financing terms, shorten the payback times for solar projects, and increase the economic value of the projects. Bundling solar energy projects with energy conservation measures is needed to lower the simple payback term for solar energy installations. Contracts that allow front-loading of the revenue stream would increase the near-term return of the project and increase later term savings for the government when conventional energy prices are higher. The measures suggested in this report will help ameliorate the effect of long payback periods for solar systems. The associated market stimulation would also help the industry raise production levels and lower the costs of solar equipment and systems, further reducing the payback-period burden. 
This study emphasizes the current ESPC system. Other considerations concerning solar payback times that are beyond the scope of this study pertain to prevailing energy prices and national environmental and energy policies. Over time, the Federal government might be willing to analyze whether air emission reductions attributed to solar energy could be valued in the contracts negotiated for such systems.

Another policy option could be for the Federal government to increase the value of financial incentives offered for solar energy systems. These types of policy actions would affect performance contracting conditions because they would help address the payback-period issue, but they cannot be counted on in the near term. These recommendations would help solar companies and ESCOs deal with the paybackperiod issue they face now.

\section{What We Can Do About Costly, Time-Consuming Contract Requirements}

Several major barriers relate directly to the standardized energy savings performance contract itself. The process for identifying project opportunities and concluding negotiations is long, costly, and difficult, and this is especially true for small companies that have expertise in renewable energy. If the Federal government wants to encourage the deployment of solar energy technologies in its facilities, it must modify the mechanism (the ESPC) that it has chosen to help accomplish this goal. The standard contract has been developed largely with energy conservation measures in mind, not solar projects. There are many differences, so the standard ESPC should be scrutinized and revised to encompass solar energy projects. The recommendations that follow address these concerns.

\section{Recommendations}

Remove Davis-Bacon Wage Act Requirements - Davis-Bacon wage requirements should be eliminated from these types of contracts. When project funding is private, Davis-Bacon requirements are seen as inappropriate. It is particularly burdensome for the smaller companies that form the core of firms attempting to develop solar energy projects. Eliminating this requirement would not preclude firms that are paying union scale from continuing to do so.

Remove Performance and Payment Bond Requirements - Given the longer payback times for renewable energy projects, anything that adds costs to a project hurts the prospects for a technology to be adopted by an ESCO or developed by a renewable energy company. Bonds can be particularly expensive and difficult for small companies to obtain. Performance and payment bonds do not seem warranted when projects do not involve government investments.

Relax the Proof-of-Financing Requirement - Providing proof of financing within 30 days after acceptance of a project installation plan can be difficult, if not unrealistic, for small businesses. Large companies have enough financial strength that proof of financing is a non-issue, but small businesses typically do not have a well-financed parent firm or a standing arrangement with a financial partner. The due-diligence contract negotiations between a solar company and a financial firm can and often do consume much longer than the 30 days stipulated in the ESPC. The 30-day requirement should be relaxed to at least 120 days.

Review End-Of-Contract Equipment Ownership Issues and Options — The government offers the incentive of a $10 \%$ Federal tax credit to the owner of the solar equipment in a solar project. However, if the government automatically becomes owner of the equipment at the end of the contract period (as stipulated in current Super ESPCs), the tax credit may be unavailable under certain financing arrangements. This legal and financial issue should be explored to see if the ESPC contract should be modified to allow the contractor to continue to own the equipment, sell it, or negotiate a new term for it. 
Relax DOE Reporting Requirements - Super ESPCs require contractors to report to DOE on a monthly basis; this is too frequent and creates unnecessary reporting. The requirement is often simply ignored, but it should be relaxed (perhaps to quarterly reports) or removed.

\section{Discussion}

The survey clearly showed that ESCOs have serious concerns about the amount of time it takes to complete ESPC negotiations, and the added costs of compliance with certain terms and requirements. These concerns are even more significant for small companies, the ones that prevail in the solar industry. These recommendations pertain to specific contract provisions in the standard Super ESPC agreement and are more technical and legal in nature. Some of the recommendations will require legal and/or contractual review. However, the goal should be to revise ESPCs to help remove barriers while staying in compliance with Federal Acquisition Regulations and EPAct requirements.

\section{What We Can Do About the Need for Information on Solar Systems and ESPCs}

A number of ESCOs said they are willing to consider adding solar systems to their projects, but to gain the knowledge need to make this decision, they would have to spend a considerable amount of time and money learning about renewable technologies. They also have reservations about the economic viability of solar systems and the staying power of solar energy companies. Also, government contracting officers appear to need more knowledge about energy performance contracting and the ins and outs of standard and technology-specific ESPCs. The following recommendations address these issues.

\section{Recommendations}

Create a FEMP Solar Facilitator System - DOE FEMP has an aggressive and instructive information program dedicated to expanding energy efficiency and renewable energy in Federal facilities. To complement this program, a targeted educational effort should be made to enhance the prospects of specific project development opportunities. Because ESCOs are willing to consider adding solar installations to their projects, this educational effort needs to be directed to the facility contracting officers who are responsible for negotiating work under ESPCs. Facilities and management personnel having technical responsibility for the project should also receive information about solar energy installations. Contracting officers would also benefit from assistance in speeding up the process of negotiating and signing energy performance contracts that include solar energy.

FEMP should create a facilitator/coordinator position that would be filled by a person familiar with solar energy technologies and energy performance contracting. This person should be available to contracting officers at any Federal facility involved in negotiating a solar energy system project under an ESPC. In addition, a similarly trained person should be located at each Federal agency known to have facilities with significant potential for solar energy installations. To start up this system, a FEMP ESPC Solar Facilitator could travel to prospective project sites with a designated facilitator from the agency that owns or occupies the site. For example, a contracting officer involved with a project proposed for an Army facility could receive help from a FEMP facilitator until a DoD facilitator felt able to help guide the project alone. FEMP could begin by identifying potential solar ESPC facilitators in the various DoD branches, such as the Navy, the Army, and the Air Force.

Set Up a Workshop for Financing Groups, the Solar Industry, and FEMP Facilitators - The recommendation for a FEMP Solar Facilitator does not address the need for finance companies to be more willing to offer long-term financing for ESPCs that include solar energy. FEMP could start, however, by including some finance company representatives in training workshops for ESPC Solar 
Facilitators. FEMP could announce this opportunity to finance companies through its normal outreach activities and by contacting finance companies participating in ESPCs. An incentive to participate might be for FEMP to pay for travel and accommodations, if possible. Interested solar companies could also be invited to attend and make presentations. This should help finance companies with the due diligence process and put them in contact with vendors and ESCOs already participating in Technology-Specific ESPCs. They would also meet the facilitators that would be providing further information and assistance.

Produce a Solar-Oriented Educational CD or Web Site - FEMP should sponsor production of a generic industry CD or an Internet Web site on solar technologies suitable for those interested in or actually implementing ESPCs. The ESCO, the finance company, and contracting officers would have at their desks a briefing package containing text, charts, tables, regulations, illustrations, documents, and tutorials. Distribution could be through the FEMP Help Desk, the EREN Web site on the Internet, advertisements in FEMP Focus, and TeleFEMP broadcasts. The solar companies could use the CDs to educate various ESCOs as well as government agencies. ESCOs could refer to it when they decide to bundle a solar project with energy conservation measures.

\section{Discussion}

The solar industry and the Federal government have worked for more than 20 years on developing and commercializing renewable energy technologies; tremendous progress has been made. The cost of solar equipment has decreased, performance has increased, and reliability has improved. At the same time, however, market conditions, such as low conventional energy costs, have dampened the prospects for wider application of solar energy technologies. The solar companies that have been working in this environment are quite skilled, but they have to contend with very difficult conditions. The need to thoroughly educate prospective partners and customers about solar technologies adds time and costs that small businesses are ill-equipped to bear.

DOE and FEMP have produced many information products about solar energy, and the Million Solar Roofs Initiative has helped to expand sales of PV and solar thermal systems. The survey results show that reliable sources of information are needed for ESCOs, their financial partners, government facility managers, and contracting officers. The recommendations in this report should complement FEMP's broader educational goals while focusing on the need to reach and train all participants in the ESPC process about the potential for solar energy installations in the Federal sector. 


\section{Appendix \\ The Telephone Survey}

\section{The Survey}

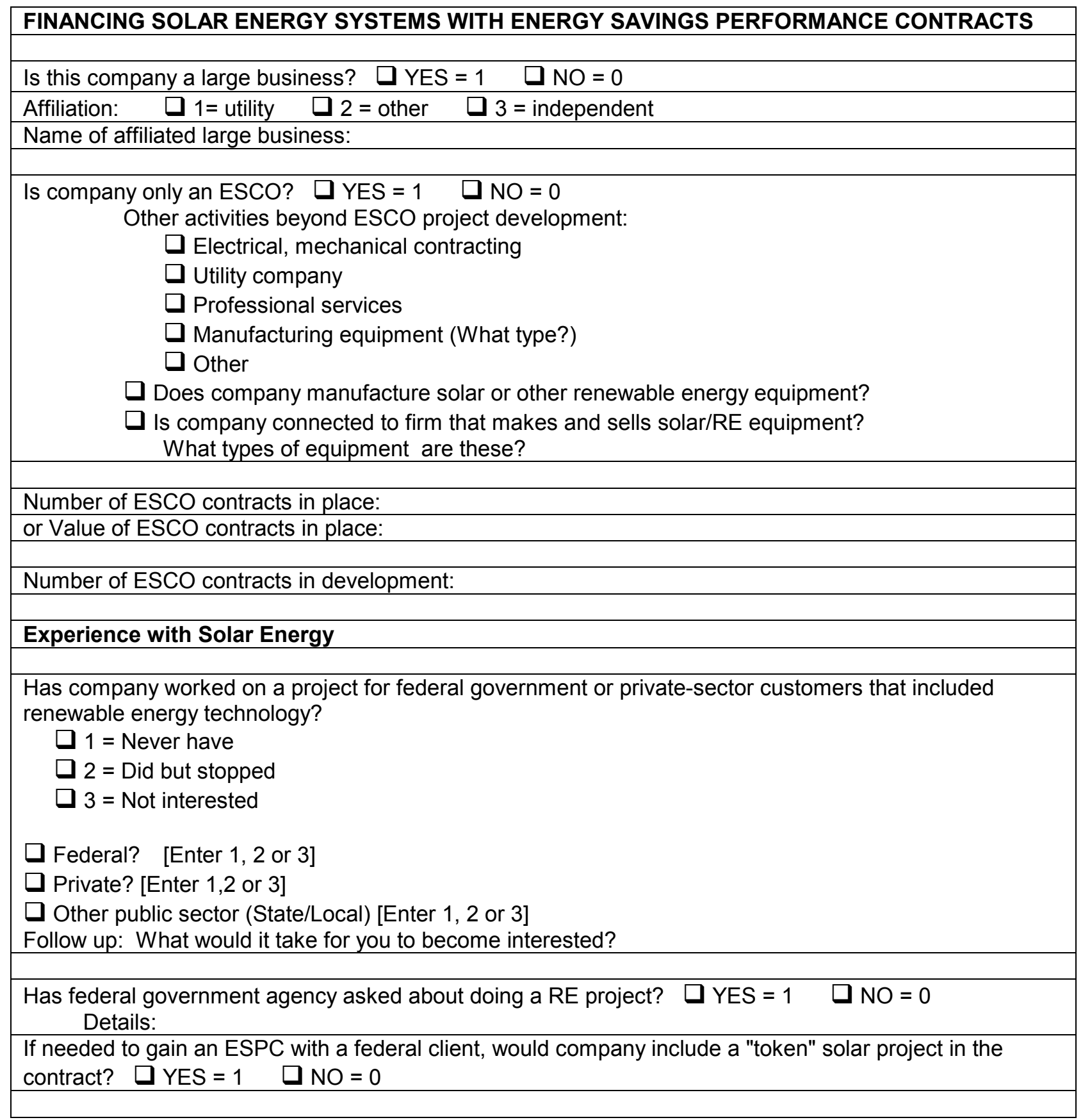




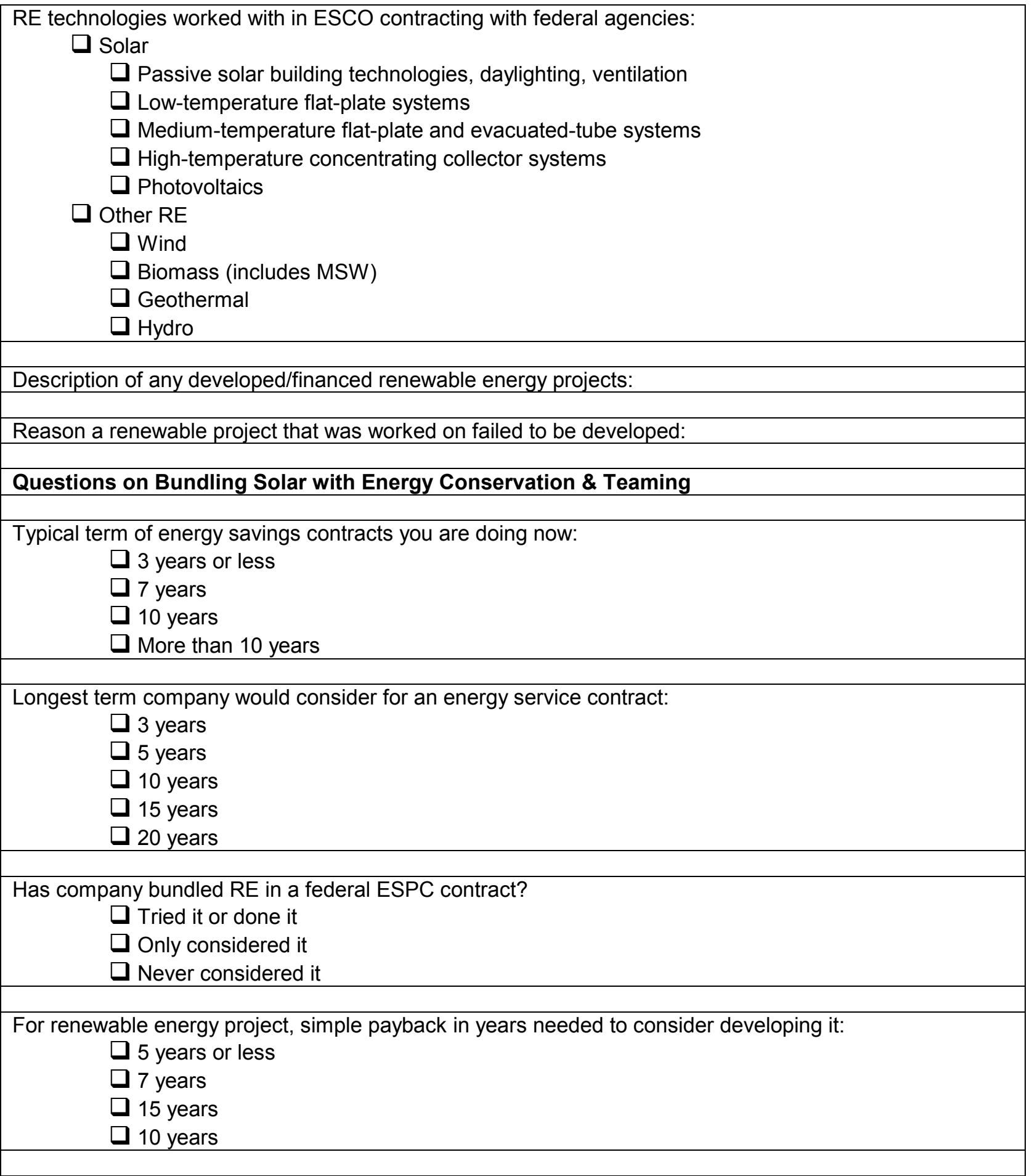




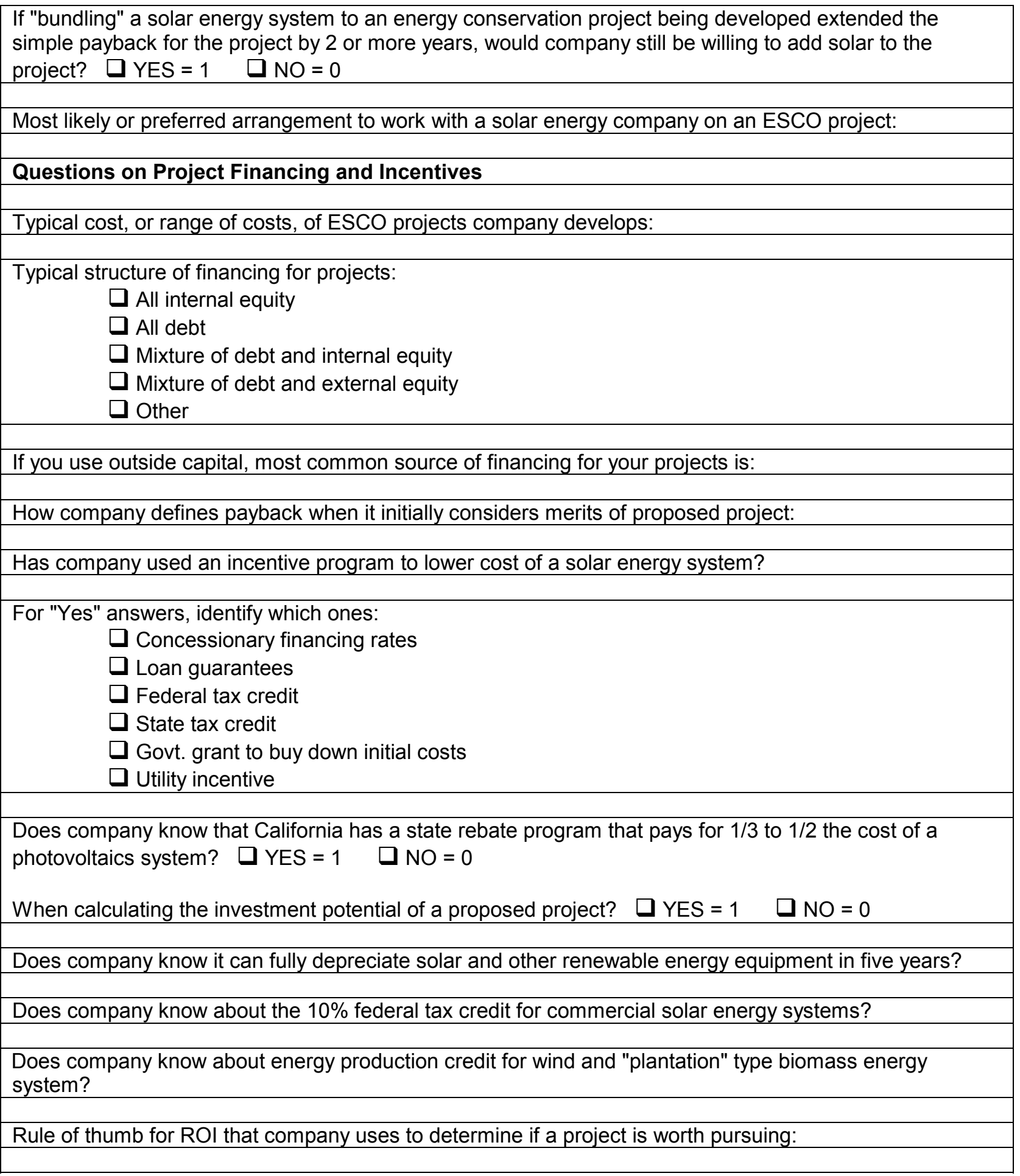




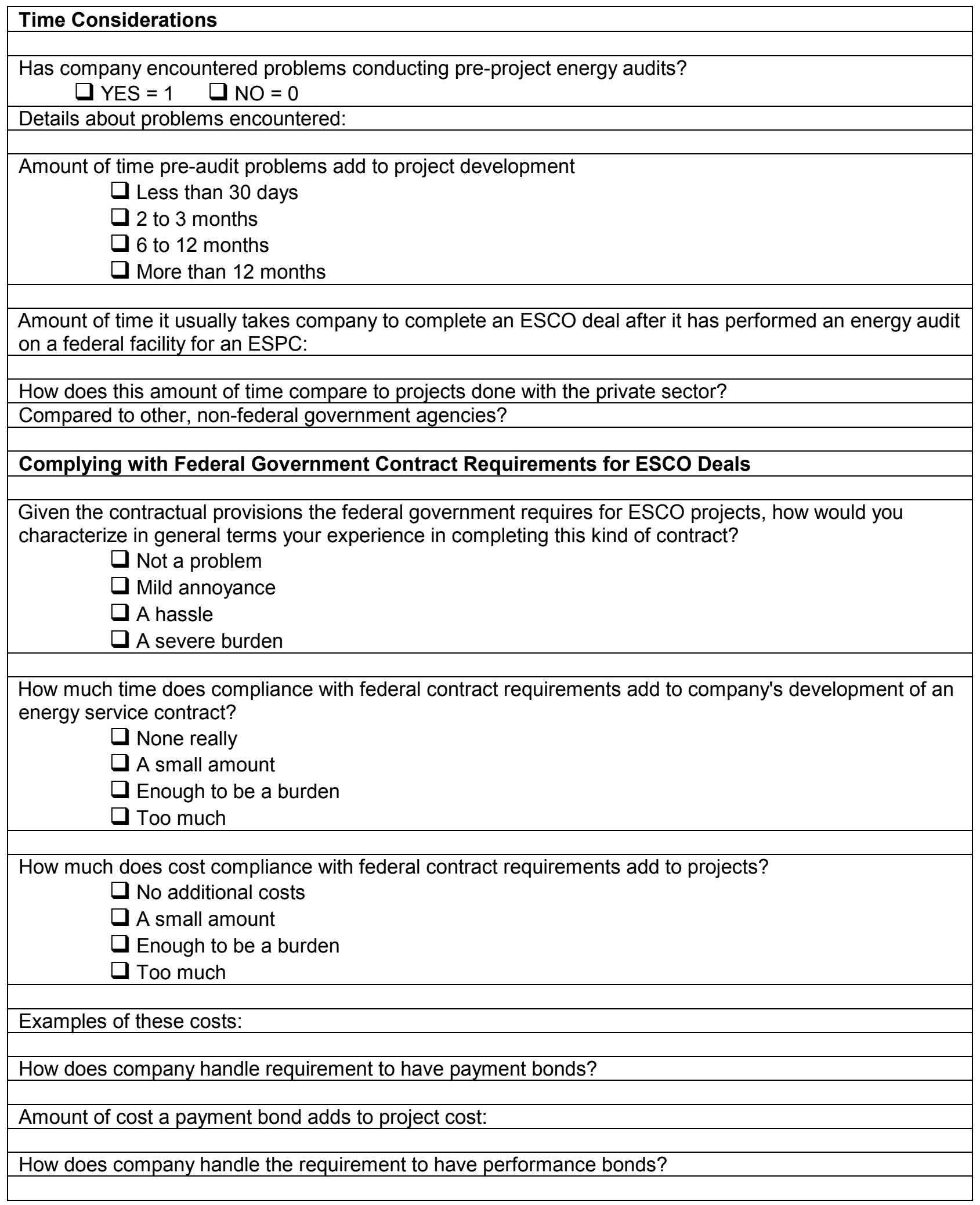




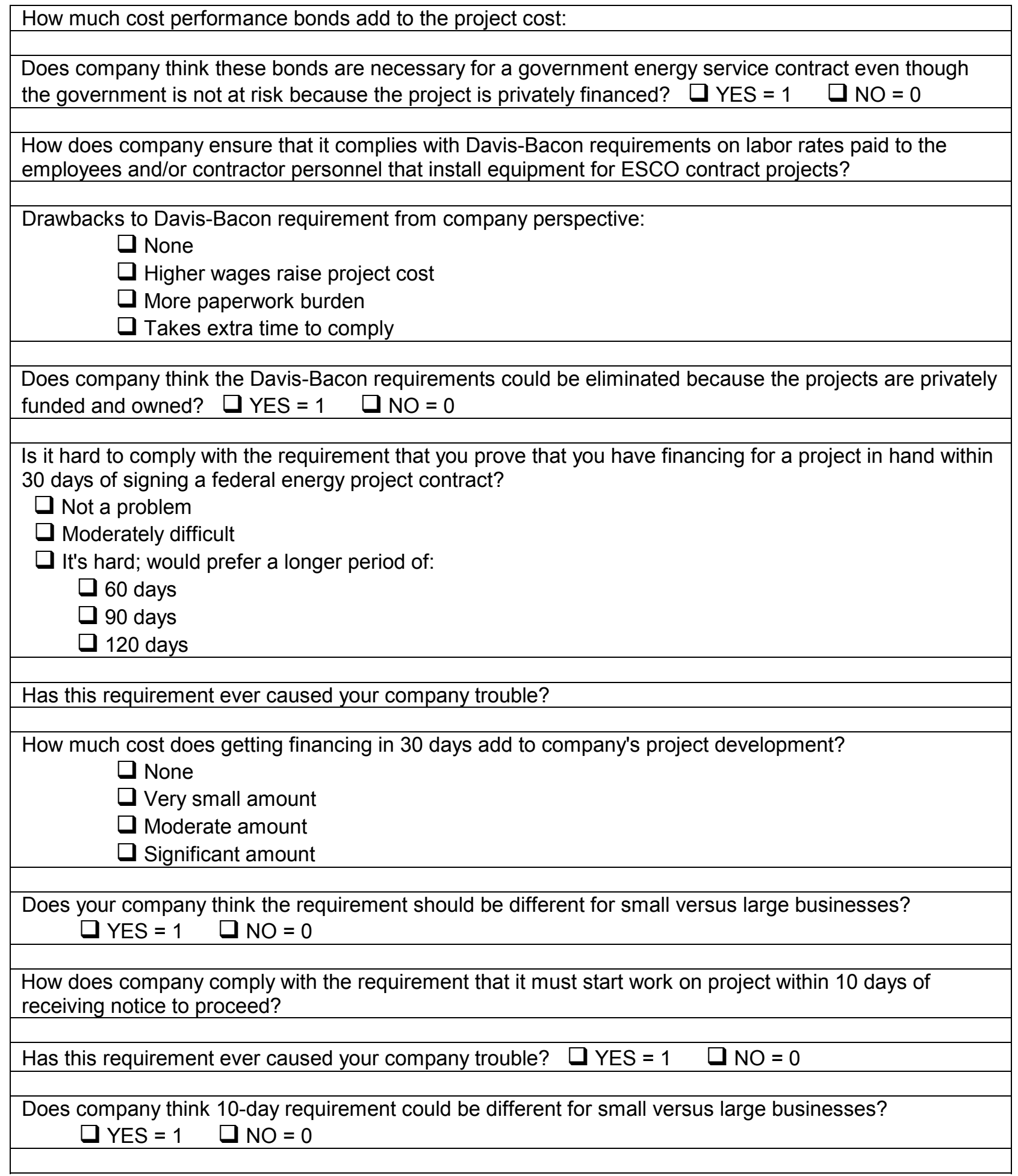




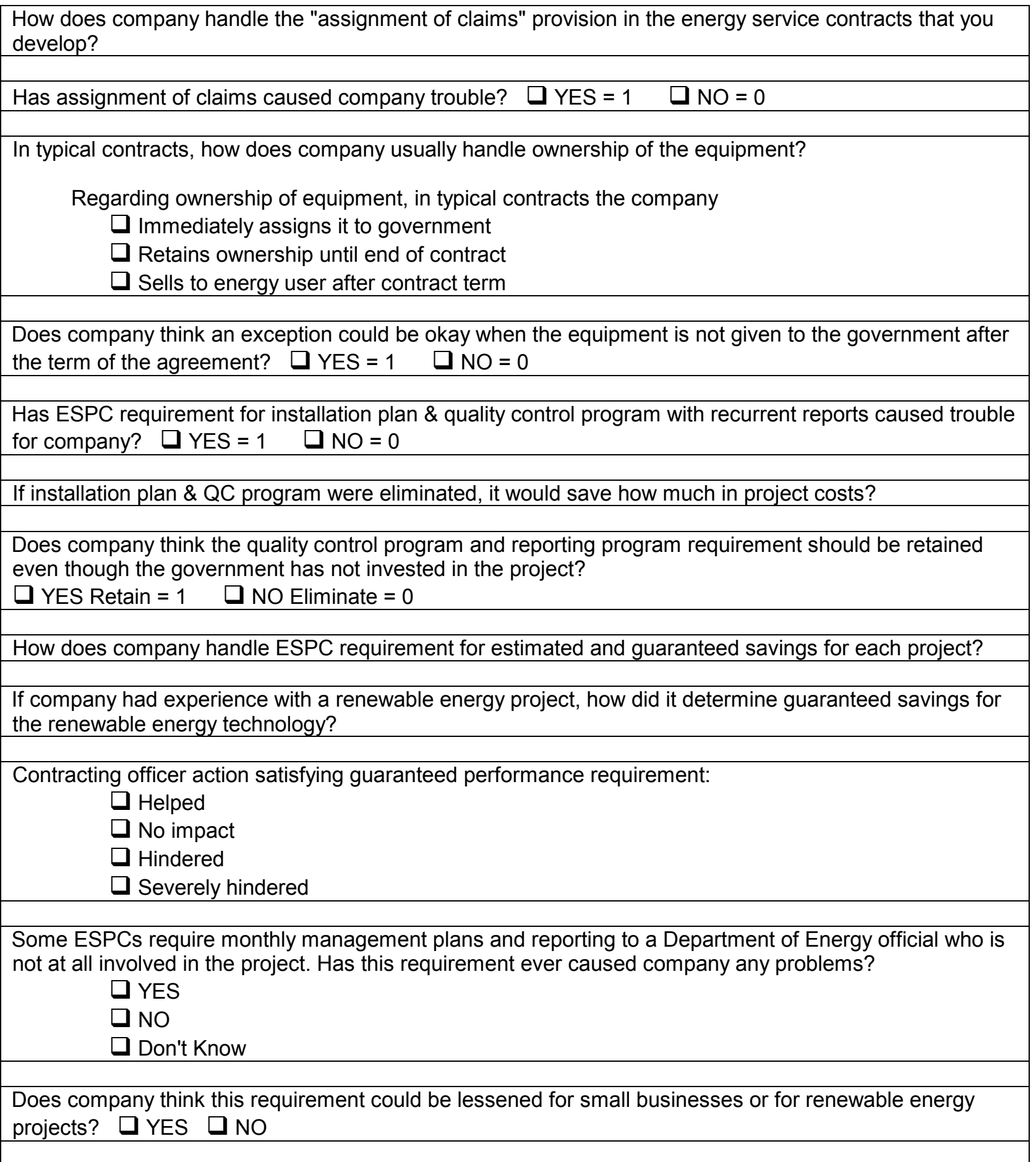


When it comes to contracts that involve solar energy or RE energy technology, what does company think are the main risks for ESCOs?

How does company think ESCOs deal with solar project risks?

$\square$ Raise rate of return requirement

$\square$ Bundle

$\square$ Keep solar a small portion of the project

$\square$ Require performance guarantees for solar companies

$\square$ Other

What does company think are the main risks for the federal government in ESCO contracts that involve solar or other renewable energy technologies? 


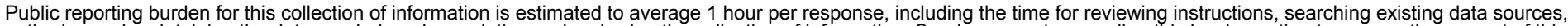

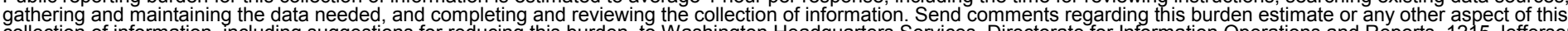
Headquarters Services, Directorate for Information Operations and Reports, 1215 Jefferso Davis Highway, Suite 1204, Arlington, VA 22202-4302, and to the Office of Management and Budget, Paperwork Reduction Project (0704-0188), Washington, DC 20503.

\begin{tabular}{|l|l|l} 
1. AGENCY USE ONLY (Leave blank) & $\begin{array}{l}\text { 2. REPORT DATE } \\
\text { July } 1999\end{array}$ & $\begin{array}{l}\text { 3. REPORT TYPE AND DATES COVERED } \\
\text { Subcontract Report, May 1998-January 1999 }\end{array}$
\end{tabular}

4. TITLE AND SUBTITLE Financing Solar Energy Systems with Energy Savings Performance Contracts in the Federal 5. FUNDING NUMBERS Sector: Results of a Survey on Barriers FE91.6020

6. $A U T H O R(S)$

Randy C. Gee and Carlo LaPorta

\section{PERFORMING ORGANIZATION NAME(S) AND ADDRESS(ES)}

Work performed by Industrial Solar Technology Corporation for the

National Renewable Energy Laboratory

1617 Cole Boulevard

Golden, Colorado 80401-3393

9. SPONSORING/MONITORING AGENCY NAME(S) AND ADDRESS(ES)

U.S. Department of Energy

1000 Independence Ave., SW

Washington, DC 20585

11. SUPPLEMENTARY NOTES

NREL Technical Monitors: Patrina Eiffert, Ph.D., and Douglas Dahle
8. PERFORMING ORGANIZATION REPORT NUMBER

SR-710-26700

10. SPONSORING/MONITORING AGENCY REPORT NUMBER 12a. DISTRIBUTION/AVAILABILITY STATEMENT

National Technical Information Service

U.S. Department of Commerce

5285 Port Royal Road

Springfield, VA 22161 12b. DISTRIBUTION CODE

13. ABSTRACT (Maximum 200 words) This report summarizes the findings of an investigation into financing solar energy systems for the Federal sector. The objectives of the investigation were (1) to identify the barriers that impede companies from using Energy Savings Performance Contracts (ESPCs) to develop solar energy projects for Federal facilities, and (2) to clarify the impacts of Federal contracting requirements on energy service companies' use of ESPCs. Twenty-four representatives of energy service companies agreed to be interviewed. Their responses indicate that these are the primary barriers to greater use of ESPCs: the relatively long payback periods for investments in solar technologies; the length of the ESPC process; the cost of certain contractual requirements regarding wages and financing; and a lack of knowledge about the actual cost and reliability of solar systems. The report proposes a number of actions the government could take to remove these barriers, including (1) streamlining and shortening the ESPC process and (2) doing more to inform both government agencies and energy service companies about the costs and benefits of solar systems.

14. SUBJECT TERMS

Solar energy, Federal buildings, energy services, performance contracts

15. NUMBER OF PAGES

16. PRICE CODE

17. SECURITY CLASSIFICATION OF REPORT unclassified
18. SECURITY CLASSIFICATION OF THIS PAGE unclassified
19. SECURITY CLASSIFICATION OF ABSTRACT unclassified
20. LIMITATION OF ABSTRACT

UL 